\title{
RELATIONSHIP OF LEADER SUPPORT WITH EMPLOYEE WORK ACHIEVEMENT AT SEI SUKA DISTRICT PUSKESMAS SEI SUKA BATU BARA DISTRICT 2019
}

\author{
Firdha Muharraran ${ }^{1}$, Ivan Elisabeth Purba ${ }^{2}$, Donal Nababan ${ }^{3} \bowtie$ \\ Lecturer at the Faculty of Dentistry, Prima Indonesia University, Medan, Indonesia. \\ ${ }^{2,3}$ Postgraduate Lecturer at Sari Mutiara Indonesia University, Indonesia.
}

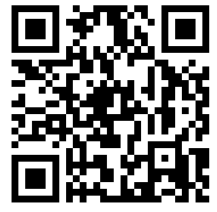

Received 4 November 2021

Accepted 15 December 2021

Published 31 December 2021

CorrespondingAuthor

Donal Nababan,

nababan_donal@yahoo.com

DOI

10.29121/granthaalayah.v9.i12.2021 .4444

Funding: This research received no specific grant from any funding agency in the public, commercial, or not-for-profit sectors.

Copyright: (C) 2021 The Author(s). This is an open access article distributed under the terms of the Creative Commons Attribution License, which permits unrestricted use, distribution, and reproduction in any medium, provided the original author and source are credited.

\section{ABSTRACT}

Background: The national health system is essentially an order that reflects the efforts of the Indonesian people to increase their ability to achieve health status. Puskesmas is a leading health service organization unit that provides comprehensive and integrated health services to the community. Human resource management is a planning, organizing, coordinating, implementing, and supervising the procurement, development, provision of remuneration, integration, maintenance, and separation of workers in order to achieve organizational goals. One way to improve resource management is leadership support for outstanding employees.

Purpose: This study aims to determine the relationship between leadership support and employee performance at the Sei Suka Health Center, Sei Suka District, Batu Bara Regency in 2019.

Method: This research was conducted cross sectional with data collection method (questionnaire). Each group with an age range of 20-30 years, 31-40, 41-50, 51-60 was given a questionnaire to fill out. Determination of the relationship between leadership support and employee performance can be seen from the results obtained after filling out the questionnaire, then the data is analyzed using the chi-square test.

Results: The results obtained that the most respondents in the category of good leadership support as many as 16 people $(48.5 \%)$ had poor work performance and the least was good leadership support 2 people $(6.1 \%)$ had good work performance after being tested with the chi test square can be seen that the value of Significancy $\mathrm{p}$ value $=$ $0.003(P<0.005)$ which shows that the relationship between leadership support and employee performance is significant.

Conclusion: there is a significant relationship between leadership support and employee performance.

Keywords: Puskesmas, Leadership Support Relationships, Employee Work Performance

\section{INTRODUCTION}

Health human resources (HR) is an arrangement that brings together various planning, education and training efforts and is integrated and mutually supportive, in order to ensure the achievement of the highest degree of public health, one of which plays an important role is the puskesmas Adisasmito (2014).

Puskesmas is a leading health service organization unit providing comprehensive and integrated health services to the community in a certain area which includes promotive, preventive, curative and rehabilitative aspects. In 
other words, the puskesmas has the authority and responsibility for the maintenance of public health in its working area. Purwoastuti and Walyani (2015)

HR management is very important for companies in managing, regulating, and utilizing employees so that they can function productively to achieve company goals Mangkunegara (2015).

One way to improve HR management is leadership support for outstanding employees. According to Russell in Sutrisno (2016), achievement is a record of the results obtained from certain job functions or certain activities during a certain period of time.

According to Maier in Sutrisno (2016) In general, work performance is defined as a person's success in carrying out a job. Information about the high and low work performance of an employee is obtained through a long process, namely the process of evaluating employee performance which is called performance appraisal.

Based on previous research Farida (2016), at RSU Aisyiyah Ponorogo, the manager considers that the employee's work performance is still not optimal, so it is necessary to evaluate the employee's work performance that can be satisfactory. According to the HR section of RSU 'Asyiyah Ponorogo, in the last 3 years there have been 6 permanent employees whose promotions have been delayed from a total of 311 employees due to poor work performance. The reason for the delay in his rank and not having his contract extended was due to poor work performance, this indicates one indicator of the employee's performance appraisal that is not good, due to lack of leadership and lack of communication.

Research result (Sustainable, 2015) it can be seen that the magnitude of the coefficient for task orientation leadership is $24.8 \%$ and this influence is positive. This means that if the leader improves the task-oriented leadership style, the employee's work performance will increase by $24.8 \%$. While the magnitude of the coefficient for the relationship-oriented leadership style is $32.9 \%$ and this influence is positive. This means that if the leader improves the relationship-oriented leadership style, the work performance of the Civil Servant Cooperative (KPN) employees increases by $32.9 \%$.

The initial survey was at the Sei Suka Health Center, Sei Suka District, Batu Bara Regency with 33 employees, with the rank/class of coach/IV-a totaling 1 person, Tk.I/III-d stylists 6 people, 2 stylists/III-c, Young stylists Tk.I/III-b 3 people, Young stylists/III-a 1 person, Young stylists Tk.I/III-b 1 person, stylist/III-a 5 people, Tk.I/II-d 9 organizers 3 people, Registrar/II-c 3 people, and Young Organizer/II-a 2 people. In the last 2 years starting from 2017 it can be seen in the HR section at the Sei Suka Health Center, Sei Suka Subdistrict, Batu Bara Regency, there are many jobs that are felt to be less than optimal, such as the home visit service section to community homes which is still less than the target, the level of discipline in the presence of employees who are still often abs, and so forth.

The problem in this study is how is the relationship between leadership support and employee performance at the Sei Suka Health Center, Sei Suka District, Batu Bara Regency in 2019. This study aims toknowing the relationship between leadership support and employee performance at the Sei Suka Health Center, Sei Suka District, Batu Bara Regency in 2019.

\section{METHOD}

This research is an analytical study with a cross sectional approach, namely, to determine the relationship between leadership support and employee performance at the Sei Suka Health Center, Sei Suka District, Batu Bara Regency in 2019. 
The research was conducted at the Sei Suka Health Center, Sei Suka District, Batu Bara Regency. The time of the study was carried out from January to June 2019.

The population of this study were all employees who served at the Sei Suka Health Center, Sei Suka District, Batu Bara Regency, totaling 33 employees. Given that the population is less than 100 people, the sample in this study is the total population of 33 people.

Data processing is carried out with the following steps: Editing, Coding, Data Entry, Tabulation, Cleaning data.

Data Analysis u To see the relationship between the independent variable and the dependent variable, it is done by usingUnivariate Analysis and Bivariate Analysis.

\section{RESULT}

\subsection{CHARACTERISTICS OF RESPONDENTS}

1) Age

Respondent data by age can be seen in Table 1 below:

Table 1 Frequency Distribution by Age in Employees at the Sei Suka Health Center in 2019

\begin{tabular}{|ccc|}
\hline Category Age & Frequency (f) & Percentage (\%) \\
$20-30$ & 9 & 27.3 \\
$31-40$ & 10 & 30.3 \\
$41-50$ & 9 & 27.3 \\
$51-60$ & 5 & 15.2 \\
Total & $\mathbf{3 3}$ & $\mathbf{1 0 0}$ \\
\hline
\end{tabular}

Based on Table 1. it can be seen that the majority of 33 employees are aged 3140 years, namely 10 people (30.3\%), and a minority of $51-60$ years as many as 5 people (15.2\%).

2) Length of working

Respondent data based on length of work can be seen in Table 2 below:

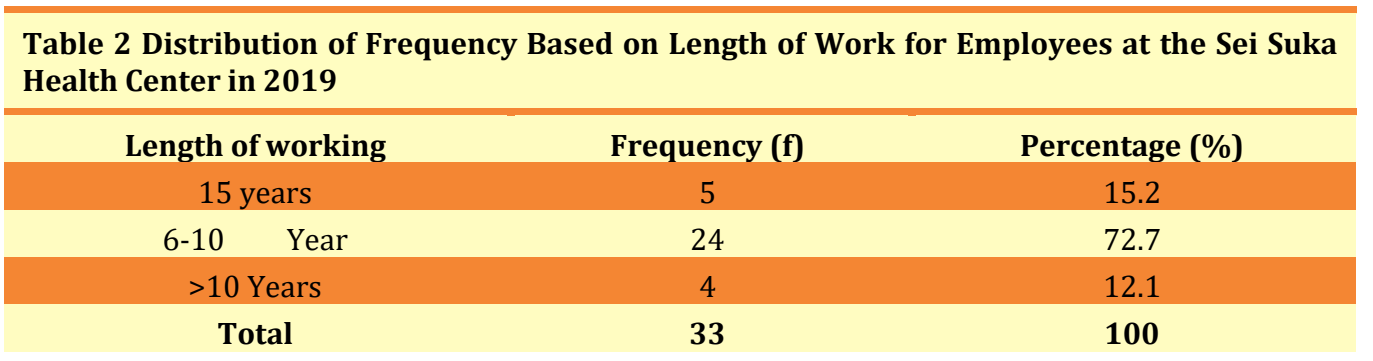

Based on Table 2. it can be seen that from 33 employees at most have worked for 6-10 years as many as 24 people $(72.7 \%)$ and at least working $>10$ years as many as 4 people $(12.1 \%)$. 
3) Marital status

Data on the marital status of respondents can be seen in Table 3 below:

Table 3 Frequency Distribution Based on Marital Status of Employees at the Sei Suka Health Center in 2019

\begin{tabular}{ccc}
\hline Status & Frequency & Percentage (\%) \\
Marry & 30 & 90.9 \\
Single & 3 & 9.1 \\
Total & 33 & 100 \\
\hline
\end{tabular}

Based on Table 3. it can be seen that of the 33 employees, most of them are married, 30 people (90.9\%) and 3 people (9.1) are unmarried.

4) Education

The education data of respondents can be seen in Table 4 below:

Table 4 Distribution of Frequency Based on the Last Education of Employees at the Sei Suka Health Center in 2019

\begin{tabular}{|ccc|}
\hline last education & Frequency & Percentage (\%) \\
3-year diploma & 15 & 45.5 \\
Undergraduate & 16 & 48.5 \\
Level 2 & 2 & 6.1 \\
Total & $\mathbf{3 3}$ & $\mathbf{1 0 0}$ \\
\hline
\end{tabular}

Based on Table 4. it can be seen that from 33 employees, 16 people (45.5\%) graduated from S1 while 2 people (6.1\%) graduated from S2.

5) Gender

Data on the sex of the respondents can be seen in Table 5 below:

Table 5 Frequency Distribution by Gender in Employees at the Sei Suka Health Center in 2019

\begin{tabular}{ccc} 
Gender & Frequency & Percentage (\%) \\
Male & 5 & 15.2 \\
Woman & 28 & 84.8 \\
Total & 33 & 100 \\
\hline
\end{tabular}

Based on table 5. it can be seen that of the 33 implementing employees, 5 people $(15.2 \%)$ are men and 28 people (84.8\%) are women.

\subsubsection{UNIVARIATE DATA}

1) Leadership Support

Data on leadership support at the Sei Suka Health Center in 2019 can be seen in Table 6 below:

Table 6 Distribution of Frequency Based on Leadership Support to Employees at the Sei Suka Health Center in 2019

Leadership Support

Not good
Frequency

15
Percentage (\%)

45.5 


$\begin{array}{lll}\text { Good } & 18 & 54.5 \\ \text { Total } & 33 & 100\end{array}$

Based on Table 6. it can be seen that of the 33 most employees, 18 people (54.5\%) have good leadership support and the lowest as many as 15 people (45.5\%) are not good leadership support.

\section{2) Employee Work Performance}

Employee work performance is the result of work in quality and quantity achieved by an employee in carrying out his duties in accordance with the responsibilities given to him. Based on the results of interviews using questionnaires that have been conducted on employees at the Sei Suka Health Center in 2019 it can be seen in Table 7 as follows:

\begin{tabular}{|ccc|}
$\begin{array}{c}\text { Table } \mathbf{7} \text { Distribution of Frequency Based on Employee Work Performance at the Sei Suka } \\
\text { Health Center in } \mathbf{2 0 1 9}\end{array}$ & \\
\hline Employee Work Performance & Frequency & Percentage (\%) \\
\hline Not good & 22 & 66.7 \\
Good & 11 & 33.3 \\
Total & $\mathbf{3 3}$ & $\mathbf{1 0 0}$ \\
\hline
\end{tabular}

Based on Table 7. it can be seen that of the 33 employees at most, 22 people $(66.7 \%)$ are employees with bad performance and 11 people $(33.3 \%)$ are good employees.

\subsubsection{THE RELATIONSHIP BETWEEN LEADERSHIP SUPPORT AND EMPLOYEE PERFORMANCE}

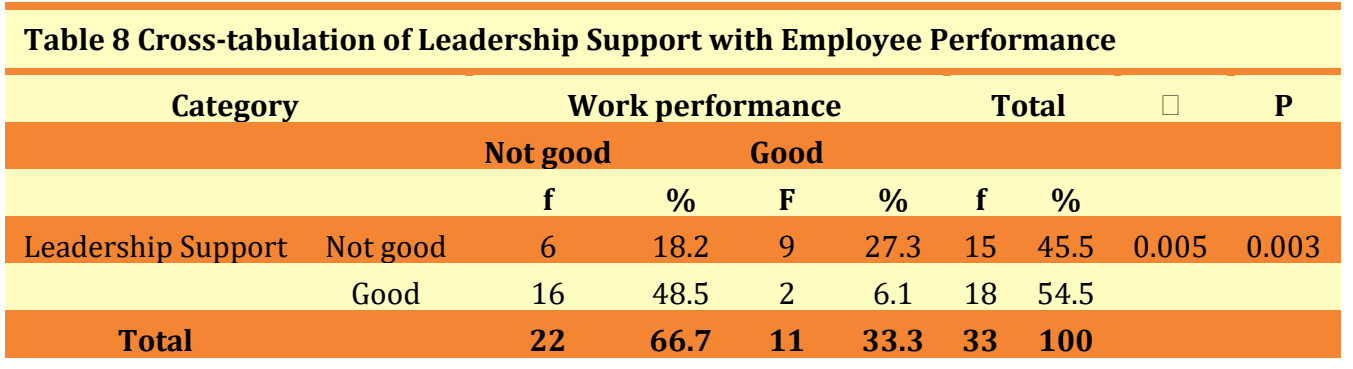

Based on Table 8. it can be seen that the most respondents with good leadership support category as many as 16 people (48.5\%) have poor work performance and the least is good leadership support 2 people $(6.1 \%)$ have good work performance after tested with the chi square test, it can be seen that the Significancy p value = $0.003(\mathrm{P}<0.005)$ which shows that the relationship between leadership support and employee performance is significant.

\section{DISCUSSION}

\section{The Relationship between Leadership Support and Employee Performance}

After being tested with the chi square test, it can be seen that the value of $p=$ $0.003(\mathrm{P}<0.005)$ This means that the relationship between leadership support and employee performance is significant. 
These results are in accordance with previous studies with the Spearmen test results $p$ value $=0.034(<0.05)$, which means that there is a relationship between leadership support and nurse work performance. Kusumastuti (2018). Leadership support is a reflection of the leadership's positive attitude in responding to an object at hand. If the leadership support is good, then the employee's work performance is good and vice versa if the leadership support is not good then the employee's work performance is not good.

Research conducted by Astuti and Prayogi (2018). also stated that there is a partial influence of leadership on employee performance, as well as work performance has a partial effect on employee performance, and simultaneously leadership and work performance have a significant effect on employee performance.

This is in accordance with the theory of leadership according to Abdillah et al. (2013). namely leadership is one of the dimensions of competence that will determine the performance of employees or the success of goals for the organization.

according to (Kartono et al., 2015) The interpersonal role possessed by a leader is that apart from being a symbol of the existence of the organization, he is also responsible for motivating and providing direction to subordinates, so that by giving special attention and support to members, they are expected to be able to do something for the organization and also various parties who have relations with the organization.

according to Farida (2016 Leadership is the core of management because leadership is the driving force for human resources and natural resources in order to achieve the goals of the organization as expected.

Meanwhile, the factors that affect work performance from the employee's point of view are Wijono (2018). is apart from the factors of expertise, interests, work situation, motivational factors play an important role in spurring human resources theoretically to boost the skills provided so that personal employees are more enthusiastic in improving work performance.

This is also in line with the research conducted Astuti and Prayogi (2018). with leadership results significant effect 0.0000 . This means that leadership has a significant effect on employee performance.

The results of the observations that the researchers found when conducting research at the Sei Suka Health Center, Sei Suka District, Batu Bara Regency, researchers could see that there was a gap between leadership support and employee performance. For example, it can be seen when the leader gives a direction in achieving work targets, where the head of the puskesmas as a leader only gives instructions during meetings, but persuasively in achieving the target, the leadership is rarely seen joining a work team, or doing evaluations in daily life together. -same with employees. In simple terms, researchers rarely see the head of the puskesmas sitting together or communicating intensely with the employees, or just laughing and joking is also rare.

It is not uncommon for puskesmas employees to be seen late in absenteeism, even puskesmas employees sometimes come just to take attendance and then go to take care of other jobs outside of their main responsibilities as puskesmas employees. In service achievement targets, it is also often found that data does not match expectations, such as the schedule of visits to carry out health promotions to schools that do not achieve operational targets.

The success of the Puskesmas program is highly dependent on the ability of its leaders. With the abilities possessed by a leader, it can affect the performance of 
subordinates to do work in accordance with the vision and mission that has been set by the Puskesmas. Today's demands require organizations and the people involved to work with high integrity. So that what is the target for the success of the planned program can be measured, evaluated and achieved to the maximum.

\section{CONCLUSION}

Based on the results of the research and discussion, the conclusion in this study is that there is a relationship between leadership support and employee performance at the Sei Suka Health Center, Sei Suka District, Batu Bara Regency in 2019. The head of the Puskesmas is expected to be firm in applying work discipline, as well as creating a mutually motivating work situation in evaluating employee performance or achievement. Employees are expected to be able to establish harmonious communication between leaders and colleagues, active in self-quality development.

\section{REFERENCES}

Adisasmito, W. (2014). Sistem Kesehatan edisi kedua. Bandung : PT. RajaGrafindo Perkasa.

Anita, J., Aziz, N., \& Yunus, M. (2013). Pengaruh Penempatan dan Beban Kerja Terhadap Motivasi Kerja dan Dampaknya Pada Prestasi Kerja Pegawai Dinas Tenaga Kerja dan Mobilitas Penduduk Aceh. Jurnal Manajemen, 2(1), 67-77. Retrieved from https://d1wqtxts1xzle7.cloudfront.net/57694556/6.67.77.Julia_Anita1with-cover-page-

v2.pdf?Expires=1641792119\&Signature=Qzd9eJFbyTMdH9ITzDxSeVFZ6R dxLOgVQbAecpBDGj-

qHwSlb717nC6rFzO8QDBjbl5c2F5SRvIrOsT3I08L0 txtFKVMEvv72zbSJxs inspeOmAknQ4vjyUVUQ7Jd6aBc9hnYIR jN8cwNcQxGnUHrmQzu1YdzqE KITICiWFurkpXbexHVh-V7vxZvtLFd-ws38TydYVxzhV9zNg2LodITOlrKkUBGDSssT0tKKnuX7GDiyfjELzOI Qii -

BkTQYGq13LisQt4Z1PeWdIqm3JuIrm7sApDFmem6Fm5Mw6oqwnJmNHT mVRkQTxKXiHluigvcNNbGYTDY41Fi8UNw_\&Key-Pair-

Id=APKAJLOHF5GGSLRBV4ZA

Astuti, R., \& Prayogi, I. (2018). Pengaruh Kepemimpinan dan Prestasi Kerja terhadap Kinerja Karyawan Pada PT. Karya Hevea Indonesia Afdeling Hevea Dolok Masihul. Prosiding : The National Conferences Management and Business (NCMAB) 2018, 490-502.

Farida, U. (2016). Pengaruh komunikasi Terhadap Prestas Kerja Karyawan dan Kepemimpinan Sebagai Variabel Moderating di Rumah Sakit Umum Aisyiyah Ponorogo. Prosiding Seminar Nasional Hasil-Hasil Penelitian 2016 : Bidang Agama Islam, Budaya, Ekonomi, Sosial Humaniora, Teknologi, Kesehatan, Dan Pendidikan, 121-123.

Kartono, K. (2017). Pemimpin Dan Kepemimpinan. Jakarta : PT. RajaGrafindo Persada.

Keputusan Menteri Kesehatan RI. (2004). KepMenKes No.128/MenKes/Kep/2004

Kusumastuti, N. E. (2018). Hubungan Antara Gaya Kepemimpinan Otoriter Terhadap Subjective Well-Being Pada Karyawan. Universitas Sanata Dharma Yogyakarta, 2, 227-249. 
Lestari, D. (2015). Pengaruh Gaya Kepemimpinan Terhadap Prestasi Kerja Karyawan (Studi Pada Koperasi Pegawai Negeri). Jurnal JIBEKA, 9(1), 23-28.

Mangkunegara, A. P. (2015). Sumber Daya Manusia Perusahaan (12th ed.). Bandung : Remaja Rosdakarya.

Mujiati, N. W., Koman, A., \& Anak A. S. (2009). Prilaku Organisasi. Bandung : Graha Ilmu.

Mustafa., \& Maryadi, Z. (2017). Kepemimpinan Pelayan (Dimensi Baru Dalam Kepemimpinan). Yogyakarta : Celebes Media Perkasa.

Notoatmodjo, S. (2016). Metodologi Penelitian Kesehatan. Jakarta : Rineka Cipta.

Nur Shabri Abdillah, M., Indar, \& Darmawansyah. (2013). STUDI GAYA KEPEMIMPINAN KEPALA PUSKESMAS DALAM PENERAPAN FUNGSI MANAJEMEN DI PUSKESMAS LAMPA KABUPATEN PINRANG Study of Leadership Style The Head of Public Health Center In The Implementation The Functions of Management In Lampa Public Health Center Pinra. 1-10.

Perturan Menteri Kesehatan RI. (2014). PerMenKes No.75/MenKes/Per/2014

Pratiwi, A., Yani, J. A., Pos, T., \& Surakarta, I. P. (2016). Kajian Penerapan Model Praktik Keperawatan Profesional (Mpkp) Dalam Pemberian Asuhan Keperawatan Di Rumah Sakit. Jurnal Kesehatan ISSN 1979-7621, 1, 73-80.

Purwoastuti, E., \& Walyani, E. S. (2015). Mutu Pelayanan Kesehatan \& Kebidanan. Semarang : Pustaka Baru Press.

Rahayu, S. (2018). Pengaruh Motivasi dan Disiplin Kerja Terhadap Prestasi Kerja Karyawan Di PT. Langkat Nusantara Kepong Kabupaten Langkat. Jurnal Manajemen Tools, 9(1), 115-132.

Siagian, S. P. (2014). Sumber Daya Manusia. Jakarta : Bumi Aksara.

Sutrisno, E. (2016). Manajemen Sumber Daya Manusia (8th ed.). Jakarta : Prenada Media Group.

Thoha, M. (2015). Kepemimpinan Dalam Manajemen. Jakarta : PT. RajaGrafindo Persada.

Wijono, S. (2018). Kepemimpinan Dalam Perspektif Organisasi. Jakarta : Pranedamedia Group 